\title{
SOCIAL INNOVATION IN ENGINEERING EDUCATION Sociālās inovācijas inženierizglītībā
}

\author{
Andreas Ahrens \\ Hochschule Wismar, University of Technology, Business and Design, Germany \\ E- mail: andreas.ahrens@hs-wismar.de \\ Jel̦ena Zaščerinska \\ Centre for Education and Innovation Research, Latvia \\ E-mail: knezna@inbox.lv
}

\begin{abstract}
Traditionally, engineering students are provided with new knowledge by educatorstudent interaction based on educator's academic (social) knowledge or student-student interaction based on their practical (individual) knowledge. That is why engineering students lack the inter-connection between the academic and practical knowledge. However, engineering education should lead to the transformation of students' knowledge from external (social) to internal (individual) perspective. Social innovation that has become the dominant response to challenges in all the domains of modern life includes peer-learning as the subphase to create socially shared knowledge in the transformation of students' knowledge from external to internal perspective and Enterprise 3.0 as a component of social media integrated into the teaching and learning process. This allows the novel transformation of students' knowledge from external to internal perspective, as introduced in this contribution, that proceeds from teaching through peer-learning to learning to be integrated in the environments of engineering education.
\end{abstract}

Keywords: Engineering Education, Peer-Learning, Social Innovation, Social Media.

\section{Introduction}

Traditionally, engineering students are provided with new knowledge by educator-student interaction based on educator's academic (social) knowledge or student-student interaction based on their practical (individual) knowledge. That is why engineering students lack the inter-connection between the academic (social) and practical (individual) knowledge. However, engineering education should lead to the transformation of engineering students' knowledge from external (social) to internal (individual) perspective.

Social innovation has become the dominant response to challenges in all the domains of modern life. Social innovation focuses on finding efficient and sustainable solutions that create value for society in general, rather than individuals and private companies. Thus, peer-learning as the sub-phase to create socially shared knowledge in the transformation of students' knowledge from external to internal perspective and application of Enterprise 3.0 as a component of social media integrated into the teaching and learning process are social innovations in engineering education.

The inter-relationship between the transformation of engineering students' knowledge, peer-learning and Enterprise 3.0, namely, engineering students' knowledge transforms from external (social) to internal (individual) perspective, peer-learning is the sub-phase to create socially shared knowledge in the 
transformation of students' knowledge from external to internal perspective and Enterprise 3.0 is a social media, requires the transformation of engineering students' knowledge from external to internal perspective that proceeds from teaching through peer-learning to learning in the Enterprise 3.0 application within the environment of engineering education to be considered.

The meaning of key concepts of social innovation, peer-learning and social media is studied. Moreover, the study demonstrates how the key concepts are related to the idea of engineering education and shows a potential model for development, indicating how the steps of the process are related following a logical chain: defining social innovation $\rightarrow$ determining peer-learning and social media $\rightarrow$ empirical study within a multicultural environment.

The methodological foundation of the present research is formed by the System-Constructivist Theory based on Parsons's system theory (Parsons, 1976) on any activity as a system, Luhmann's theory (Luhmann, 1988) on communication as a system, the theory of symbolic interactionalism (Mead, 1973) and the theory of subjectivism (Groeben, 1986). The System-Constructivist Theory and, consequently, System-Constructivist Approach to learning introduced by Reich (Reich, 2005) emphasizes that human being's point of view depends on the subjective aspect (Maslo, 2007. p. 39):

- everyone has his/her own system of external and internal perspectives that is a complex open system (Ahrens, Zaščerinska, 2010, p. 180), and

- experience plays the central role in a construction process (Maslo, 2007, p. 39).

Therein, the subjective aspect of human being's point of view is applicable to the present research.

The methodological approach - development of the system of external and internal perspectives - of the present research proceeds from the external perspective to the internal perspective through the phase of unity of external and internal perspectives (the system of interacting phenomena) (Zaščerinska, 2011a, p. 135).

The remaining part of this paper is structured as follow: Section 2 introduces the theoretical framework on the historical development of social innovation in pedagogy, peer-learning and Enterprise 3.0 as a component of social media. The associated results of an empirical study will be presented in Section 3. Finally, some concluding remarks are provided in Section 4 followed by a short outlook on interesting topics for further work.

\section{Theoretical framework}

The theoretical framework of the present contribution involves the meaning of the key concepts of "social innovation", "peer-learning" and "social media" to be studied.

\subsection{Defining Social Innovation}

A general conception of social innovation is determined as innovative activities and services that are motivated by the goal of meeting a social need and 
that are predominantly developed and diffused through organisations whose primary purposes are social (Mulgan, Tucker, Ali, Sanders, 2007, p. 3). The study of the social innovation concept and pedagogical perspective on social innovation has started for about two centuries ago (Mulgan, Tucker, Ali, Sanders, 2007, p. 911; Arendale, 2007, p. 33) as demonstrated in Table 1.

Table 1

Social innovation in pedagogy in different historical periods

\begin{tabular}{|c|c|c|c|}
\hline Stage & $\begin{array}{c}\text { Historical } \\
\text { period }\end{array}$ & $\begin{array}{c}\text { Author of the } \\
\text { approach }\end{array}$ & Educational settings \\
\hline 1 & 1837 & $\begin{array}{l}\text { Friedrich Froebel's } \\
\text { ideas }\end{array}$ & the first kindergarten \\
\hline 2 & $\begin{array}{l}\text { 19th and } \\
\text { early 20th } \\
\text { century }\end{array}$ & Barnardos & childcare \\
\hline 3 & 1945 & Not defined & $\begin{array}{l}\text { schooling systems and } \\
\text { institutions, } \\
\text { networks of adult education } \\
\text { colleges, driving schools }\end{array}$ \\
\hline 4 & 1957 & $\begin{array}{l}\text { Joe Engressia, } \\
\text { John Draper, etc }\end{array}$ & $\begin{array}{l}\text { social media (phone } \\
\text { phreaking) for educational } \\
\text { networking }\end{array}$ \\
\hline 5 & the mid 1990s & $\begin{array}{c}\text { the City University of } \\
\text { New York }\end{array}$ & peer-led team learning \\
\hline 6 & 1998 & J. Gregory Dees & social enterprise \\
\hline
\end{tabular}

Thus, peer-learning and social media as highly important mechanisms of social change (Loogma, 2011, p. 1) integrated into the teaching and learning process are social innovations in education.

\subsection{Defining peer-learning}

Peer-learning is the sub-phase to create socially shared knowledge in the transformation of students' knowledge from external to internal perspective (Ahrens, Zaščerinska, 2011a, p. 315; Ahrens, Zaščerinska, 2011b, p. 399). It should be mentioned that peer-learning is defined as shared aim oriented joint activity according to certain common norms, over some period of time that provides joint social interaction and cognition for each participant and increases opportunities of gaining social experience.

This allows the novel transformation of students' knowledge from external to internal perspective that proceeds from teaching in Phase 1 through peer-learning in Phase 2 to learning in Phase 3 to be integrated in the environments of engineering education (Zaščerinska, Ahrens, 2010, p. 184).

Each phase of the process of teaching and learning is separated from the previous one, and the following phase is based on the previous one (Ahrens, Zaščerinska, 2011b, p. 399):

- The teaching phase starts with preparing the students for the process of teaching and learning, planning the procedure of the process of teaching and learning, equipping teaching/learning class, determining the purpose, etc. 
- Then, the peer-learning phase is aimed at doing an exercise and making a decision.

- The learning phase focuses on the evaluation of both individual achievements and results. Students gradually move from the external regulation and evaluation in Phase 1 to the self-regulation, mutual evaluation and selfevaluation in Phase 3.

\section{Empirical research}

The research design within the present research comprises the research methodology, the sample of the present research and the research findings considered.

\subsection{Research Methodology}

This study is oriented towards the revealing of effectiveness of application of Enterprise 3.0 as a component of social media in engineering curriculum based on the transformation of students' knowledge from external to internal perspective that proceeds from teaching in Phase 1 through peer-learning in Phase 2 to learning in Phase 3 within the Baltic Summer School Technical Informatics and Information Technology at Riga Technical University, Riga, Latvia, August 12-27, 2011. Its topicality is determined by ever-increasing flow of information and business processes in which an important role is laid to Enterprise 3.0 as a means of getting information and gaining experience.

An explorative research aimed at developing hypotheses, which can be tested for generality in following studies (Mayring, 2007) has been used in the research. Interpretative research paradigm which corresponds to the nature of humanistic pedagogy has been determined for the research as it creates an environment for the development of any individual and helps them to develop their potential (Lūka, 2008, p. 52). Interpretative paradigm is characterized by the researchers' practical interest in the research question (Cohen, Manion et.al., 2003). The study consisted of the following stages:

- exploration of the context of use of Enterprise 3.0 through thorough analysis of the documents,

- analysis of the students' feedback regarding their needs in use of Enterprise 3.0,

- data processing, analysis and data interpretation,

- analysis of the results and

- elaboration of conclusions and directions for further studies.

Effectiveness is considered as the educator's contribution to the student engineers' knowledge, skills and attitudes in Enterpise 3.0 application (Zaščerinska, 2011a, p. 125-126).

Analysis of the students' feedback regarding their needs in Enterprise 3.0 application in the pre- and post-survey was based on the following questionnaire:

- Question 1: Do you have your own business and / or enterprise? The evaluation scale of two levels for the question is given where "1" means "no" and "2" "yes". 
- Question 2: Do you plan to start your own business and / or enterprise? The evaluation scale of two levels for the question is given where "1" means "no" and "2" - "yes".

- Question 3: To which extent do modern business and enterprise employ Web technologies? The evaluation scale of five levels for the question is given where " $0-20 \%$ " means a low level of experience in Enterprise 2.0 application and " 80 $100 \%$ " points out a high level of Enterprise 2.0 application.

- Question 4: Please, indicate at least 3 Web technologies used by business and / or enterprise for business applications (up to five). The evaluation scale of five levels for the question is pointed out. 1 point is given for each correct answer, thereby " 1 " means a low level of experience in Enterprise 2.0 application and " 5 " - a high level of Enterprise 2.0 application.

It should be mentioned that the emphasis of the System-Constructivist Theory on the subjective aspect of human being's point of view and experience that plays the central role in a knowledge construction process does not allow analyzing students' needs in Enterprise 3.0 objectively: human beings do not always realize their experience and their wants in use of Enterprise 3.0.

The descriptive statistics (Mean) in the SPSS 17.0 software for primary quantitative data analysis was used.

\subsection{Respondents of the Research}

The present empirical study conducted during the implementation of Seventh Baltic Summer School Technical Informatics and Information Technology at Riga Technical University, Riga, Latvia, August 12-27, 2011, involves the sample of 24 participants.

All 24 participants of Seventh Baltic Summer School Technical Informatics and Information Technology have got Bachelor or Master Degree in different fields of Computer Sciences and working experience in different fields. The International Summer School offers special courses to support internationalization of education and cooperation among the universities of the Baltic Sea Region. The aims of the Baltic Summer School are determined as preparation for international Master and Ph.D. programs in Germany, further specialization in computer science and information technology and learning in a simulated environment. Baltic Summer School Technical Informatics and Information Technology does not contain a special module on Enterprise 3.0. The Summer School Technical Informatics and Information Technology contains a special module on Web 2.0. The Web 2.0 module examines the advantages and problems of this technology, namely, architecture and management, protocol design, and programming, which makes new social communication forms possible. The Web 2.0 module does not reveal the concept of Enterprise 3.0. However, the Web 2.0 module comprises Enterprise 3.0 technologies, namely, online networks. The Web 2.0 module involves Ajax (Asynchronous JavaScript and XML) and Advanced Javascript Programming Libraries, Security for Web Portals, Web 2.0 Design Paradigms, Patterns for Rapid Web Prototyping and Ruby on Rails. 
The 24 participants of Seventh Baltic Summer School Technical Informatics and Information Technology are with different cultural backgrounds and diverse educational approaches from different countries, namely, Latvia, Lithuania, Estonia, Russia, Great Britain, China, India, Nigeria, Romanian and Mexico. Whereas cultural similarity aids mutual understanding between people (Robbins, 2007 , p. 55), the students' different cultural and educational backgrounds contribute to successful learning and become an instrument of bringing the students together more closely under certain conditions, namely, appropriate materials, teaching/learning methods and forms, motivation and friendly positioning of the educator (Abasheva, 2010, p. 431). Moreover, the sample of the participants of the Seventh Baltic Summer is multicultural. That emphasizes the study of individual contribution to the development of student engineers' Enterprise 3.0 application (Lūka, Ludborza, Maslo, 2009, p. 5). Hence, the group's socio-cultural context (age, field of study and work, language level, mother tongue) is heterogeneous

\subsection{Findings of the Research}

Results of the pre-survey of needs in Enterprise 3.0 application reveal that the student engineers do not realize the possibilities offered by Enterprise 3.0 for business properly:

- One engineering student has had his/her own business.

- 11 engineering students plan to start their own business and / or enterprise.

- Nine engineering students consider that modern business employs Web technologies to $40-60 \%, 10$ student engineers $-60-80 \%$ and five engineering students $-80-100 \%$.

- Four student engineers indicated no Web technologies used by business, two engineering student - one Web technology used by business, three engineering student - two Web technologies used by business, 14 student engineers - three Web technologies used by business and one engineering student - four Web technologies used by business.

This is a reason why a support system to contribute to students' learning outcomes in a multicultural study's context was elaborated.

Between the pre- and post-survey of the students' Enterprise 3.0 application based on the transformation of students' knowledge from external to internal perspective that proceeds from teaching in Phase 1 through peer-learning in Phase 2 to learning in Phase 3 was implemented within the Baltic Summer School Technical Informatics and Information Technology at Riga Technical University, Riga, Latvia, August 12-27, 2011, as following:

Phase 1 Teaching was aimed at a safe environment for all the students. In order to provide a safe environment, the essence of constructive social interaction and its organizational regulations were considered by both the educator and students. The present phase of Enterprise 3.0 application is organized in a frontal way involving the students to participate, namely, 
- Educator makes previous experience rational. The activity includes choice of forms and use of resources that motivates the students. Teaching process is under the educator's guidance.

- Peers do not participate in guidance of the process of teaching and learning. Activity is carried out qualitatively only with the help of the educator. Dependence on the educator is observed. The students study alongside but not together.

- Students create the system of the aim and objectives, search for a variety of information source and obtain techniques of information compiling. Students fulfil the activity qualitatively only with the educator's help. Dependence on the educator is observed, not dependent on peers.

Phase 2 Peer-Learning is designed for the students' analysis of an open academic problem situation and their search for a solution. This phase involves the students to act in peers, namely,

- Educator functions as a resource and moderator. Educator delegates his/her duties to the students.

- Peers regulate each other: it is typical for students to regulate each other. The students study together, study from others and teach others. The process of teaching and learning is under peer's guidance. Activity's forms and methods are exchanged.

- The students fulfil the activity qualitatively with the peers' help. Partial independence is observed. The relevant activity is performed jointly with other students and with shared responsibility. It is typical for students to regulate each other.

Phase 3 Learning emphasizes the students' self-regulation with use of assessment of the process and self-evaluation of the results, namely,

- Educator functions as a consultant and an assistant. Educator delegates his/her duties to the students.

- Peers have consultative and advisory functions. Students' self-regulation is typical. The students study independently.

- The students qualitatively fulfil the activity in an autonomous way, and their independence is observed. The participants' self-regulation on the basis of the process assessment and the result self-evaluation is used. The relevant activity is performed with a high sense of responsibility. Self-regulation is typical, and a student does not depend on peers.

This support system differs from the one offered by other educators as the proposed support system proceeds in a certain sequence.

After having applied Enterprise 3.0 in the Web 2.0 module, results of the postsurvey demonstrate the positive changes in comparison with the pre-survey:

- The number of engineering students who plan to start their own business increased from 11 to 16 .

- The number of student engineers who considered that modern business employs Web technologies to $40-60 \%$ decreased from nine to five, $60-80 \%$ - decreased from 10 to nine and $80-100 \%$ - increased from five to 10 engineering students. 
- The number of engineering students who indicated one or no Web technologies used by business decreased from six student engineers to 5, two Web technologies used by business - decreased from three engineering student to one, three Web technologies used by business - increased from 14 student engineers to 15 and four Web technologies used by business - increased from one engineering student to three.

- The number of students who has had his/her own business remained steady one engineering student.

The results of two surveys of the participants' experience in Enterprise 3.0 application within the Seventh Baltic Summer School 2011 demonstrate the positive changes in comparison with the pre-survey.

In order to determine the developmental dynamics of each student's learning outcome, comparison of the pre-survey and post-survey results was carried out. The Mean results of the descriptive statistics highlighted in Table 2 demonstrate that the level of the students' Enterprise 3.0 application has increased in the post-survey $(2,39)$ in comparison with the pre-survey $(2,15)$.

Table 2

Mean analysis of the pre- and post-survey in 2011

\begin{tabular}{ccc}
\hline Question & Pre-Survey & Post-Survey \\
\hline 1 & 1,04 & 1,04 \\
2 & 1,46 & 1,66 \\
3 & 3,83 & 4,21 \\
4 & 2,25 & 2,66 \\
mean & 2,15 & 2,39 \\
\hline
\end{tabular}

The results of Mean within the surveys of the students' feedback regarding their needs in Enterprise 3.0 application reveal that most of answers are concentrated around Level 2. Thus, there is a possibility to increase the students' use of Enterprise 3.0 within Web 3.0 technologies.

Hence, considering judgment to be part of the art of statistics (Gigenzer, 2004, p. 603), the conclusion has been drawn that Enterprise 3.0 application influenced the development of the engineering students' learning outcomes demonstrated by the difference between the levels of the student engineers' learning outcomes in the pre- and post-survey.

\section{Conclusions}

The empirical results reveal that the transformation of students' knowledge from external to internal perspective that proceeds from teaching in Phase 1 through peer-learning in Phase 2 to learning in Phase 3 within the Baltic Summer School Technical Informatics and Information Technology in 2011 is effective to 
contribute to the students' competences and learning outcomes in application of Enterprise 3.0 as a component of social media.

The present research has limitations. Enterprise 3.0 application in the Seventh Baltic Summer School was studied paying attention to the students' feedback regarding their needs, but it was studied in isolation from the evaluation of educators. Another limitation is the length of the research. If the results of other Baltic Summer Schools had been available for analysis, different results could have been attained. There is a possibility to continue the study.

Further research might include Enterprise 3.0 application based on five phases of the transformation of students' knowledge from external to internal perspective that proceeds (Zaščerinska, 2011b, p. 145) as following:

- teaching in Phase 1,

- teaching with elements of peer-learning in Phase 2,

- peer-learning in Phase 3,

- peer-learning with elements of leaning in Phase 4 and

- learning in Phase 5.

Table 3

Enterprise 2.0 in pedagogy in different historical periods

\begin{tabular}{|c|c|c|c|c|}
\hline Phase & $\begin{array}{c}\text { Historical } \\
\text { Period }\end{array}$ & Approach & $\begin{array}{c}\text { Elements of } \\
\text { Enterprise }\end{array}$ & Educational settings \\
\hline 1. & $2000-2006$ & $\begin{array}{c}\text { Enterprise 1.0 as } \\
\text { socialization }\end{array}$ & Social software & $\begin{array}{c}\text { Tasks with use of } \\
\text { Enterprise } 1.0\end{array}$ \\
\hline 2. & $\begin{array}{c}2006-\text { up to } \\
\text { now }\end{array}$ & $\begin{array}{c}\text { Enterprise } 2.0 \text { as } \\
\text { community }\end{array}$ & $\begin{array}{c}\text { Social software } \\
\text { and online networks }\end{array}$ & $\begin{array}{c}\text { Teaching techniques } \\
\text { with use of } \\
\text { Enterprise } 2.0\end{array}$ \\
\hline 3. & $\begin{array}{c}2007-\text { up to } \\
\text { now }\end{array}$ & $\begin{array}{c}\text { Enterprise } 3.0 \text { as } \\
\text { organization }\end{array}$ & Online networks & $\begin{array}{c}\text { Practice of } \\
\text { the Enterprise } 3.0 \\
\text { curriculum }\end{array}$ \\
\hline 4. & $\begin{array}{c}2010-\text { up to } \\
\text { now }\end{array}$ & $\begin{array}{c}\text { Enterprise } 4.0 \text { as } \\
\text { society }\end{array}$ & $\begin{array}{c}\text { Ambient } \\
\text { intelligence, WebOS } \\
\text { or Web operating } \\
\text { system, artificial } \\
\text { intelligence }\end{array}$ & University Degree \\
\hline
\end{tabular}

Another direction of further research is proposed as empirical studies in other tertiary institutions and a comparative research of different countries. Further research is proposed to deal with another social innovation in engineering education - social enterprise that is, fundamentally about using a market-driven business model to address key social and environmental issues rather than engineering students' individual and private purposes.

Enterprise 3.0 demonstrates the technology of online networks to assemble and manage large communities with a common interest in peer contribution, where organisations and enterprises have made use of the potential of Web 3.0 with single solutions such as online networks. However, Enterprise 4.0 as shown in Table 3 will be derived from the full application of Web 4.0 concepts such as ambient intelligence, WebOS or Web operating system, artificial intelligence, rather than Web 3.0 point solutions (Bassus, Ahrens, Zaščerinska, 2011, p. 381).

It should be mentioned that the concept of a Web operating system or WebOS is distinct from Internet operating systems. Web operating system or 
WebOS is independent of the traditional individual computer operating system. This remains as an open point for the future.

\section{Bibliography}

1. Abasheva, Catherine. (2010). Specifics of the English Language Education in the Study Groups with Different Mother Tongues. In M. Marnauza (Ed), 5th International Scientific Conference Theory for Practice in the Education of Contemporary Society of Riga Teacher Training and Educational Management Academy (pp. 428-431). Riga, Latvia.

2. Ahrens, Andreas, Zaščerinska, Jeļena. (2011a). Enterprise 3.0 in Engineering Education. In: G. Noviks (Ed), Proceedings of the 15th international student scientific practical conference "Human. Environment. Technology" of the Engineering Faculty of Rezekne Higher Education Institution, April 27, 2011, pp. 312-320. Rēzekne: Rēzeknes Augstskolas Izdevniecība 2011, Latvia. ISBN 978-9984-44-079-8.

3. Ahrens, Andreas, Zaščerinska, Jel̦ena. (2011b). Social Dimension of Web 2.0 in Teacher Education: Pedagogical Guidelines. In: Charles A. Shoniregun (Ed), International Journal for Cross-Displinary Subjects in Education (IJCDSE), Volume 2, Issue 2, June 2011, pp. 397-406. Copyright (C) 2011, Infonomics Society, UK.

4. Ahrens, Andreas; Zaščerinska, Jel̨ena. (2010). Social Dimension of Web 2.0 in Student Teacher Professional Development. In I. Žogla (Ed), Proceedings of Association for Teacher Education in Europe Spring Conference 2010: Teacher of the 21st Century: Quality Education for Quality Teaching (pp. 179-186). Riga, Latvia.

5. Arendale, David. (2007). Postsecondary Peer Cooperative Learning Programs: Annotated Bibliography. College of Education and Human Development University of Minnesota, Minneapolis, MN.

6. Bassus, Olaf, Ahrens, Andreas, Zaščerinska, Jel̦ena. (2011). Clustering for the Development of Engineering Students' Use of Enterprise 3.0. Proceedings of the 4th International Conference of Engineering \& Business Education and 1st SAFRI Journey to Excellence Conference $20-23$ November 2011, pp. 373-383. Published by Cape Peninsula University of Technology, Cape Town, South Africa.

7. Cohen, Louis, Manion, Lawrence, et al. (2003). Research Methods in Education. London and New York: Routledge/Falmer Taylor \& Francis Group.

8. Dees J. G. (1998). The Meaning of Social Entrepreneurship. Entrepreneur in Residence, Kauffman Center for

Entrepreneurial Leadership, Ewing Marion Kauffman Foundation and Miriam and Peter Haas Centennial Professor in Public Service, Graduate School of Business, Stanford University, October 31, 1998.

9. Gigerenzer, Gerd. (2004). Mindless Statistics. The Journal of Socio-Economics, Volume 33, Issue 5, 587-606. Elsevier Inc.

10. Groeben, Norbert. (1986). Handeln, Tun, Verhalten als Einheiten einer verstehend-erklärenden Psychologie. Tübingen: Francke.

11. Loogma, Krista. (2011). Educational Change and Social Innovation: the Role of Regional Network. The European Conference on Educational Research 2011 Urban Education, Freie Universität Berlin, Germany. 12-16 September 2011.

12. Luhmann, Niklas. (1988). Erkenntnis als Konstruktion. Bern: Benteli.

13. Lūka, Ineta, Ludborza, Sarmite, Maslo, Irina. (2009). Effectiveness of the use of more than two languages and quality assurance in European interuniversity master studies. Paper presented at the European Conference on Educational Research, University of Vienna, September 28-30, 2009.

14. Lūka, Ineta. (2008). Students and the educator's co-operation as a means of development of students' ESP competence. Paper presented at the European Conference on Educational Research "Theory and Evidence in European Educational Research", University of Goteborg, 10-12 September 2008.

15. Maslo, Elīna. (2007). Transformative Learning Space for Life-Long Foreign Languages Learning. In: D.Cunningham, D.Markus, J.Valdmanis ... [u.c.] (Eds), International Nordic-Baltic Region 
Conference of FIPLV Innovations in Language Teaching and Learning in the Multicultural Context 15-16 June, 2007, Riga, Latvia (pp. 38-46). - Rīga: SIA "Izglīitibas solii".

16. Mayring, Philip. (2007). On Generalization in Qualitatively Oriented Research. In: Forum Qualitative Sozialforschung/Forum: Qualitative Social Research, 8(3), Art. 26.

17. Mead, George. (1973). Geist, Identität, und Gesellschaft. Frankfurt: Suhrkamp.

18. Mulgan, Geoff, Tucker, Simon, Ali, Rushanara, Sanders, Ben. (2007). Social Innovation: what it is, why it matters and how it can be accelerated. Skoll centre for Social Entrepreneurship. Oxford Said Business School. The Basingstoke Press.

19. Parsons, Talcott. (1976). Theorie sozialer Systeme. Opladen: Westdeutscher Verlag.

20. Reich, Kersten. (2005). Systemisch-konstruktivistische Pädagogik. Weinheim u.a. (Beltz).

21. Robbins, Dorothy. (2007). Vygotsky's and Leontiev's Non-classical Psychology related to second Language Acquisition. In: D.Cunningham, D.Markus, J.Valdmanis ... [u.c.] (Eds), International Nordic-Baltic Region Conference of FIPLV Innovations in Language Teaching and Learning in the Multicultural Context 15-16 June, 2007, Riga, Latvia (pp. 47-57). - Rīga: SIA "Izglītības solii".

22. Zaščerinska Jel̦ena. (2011a). How to Teach Content: Existing Concepts and Prospects for Development. In: Stasys Vaitekūnas (Ed). Association for Teacher Education in Europe ATEE Spring University 2011 Changing Education in a Changing Society, Volume 1, pp. 134-149. Klaipeda University, Lithuania. ISSN 1822-2196.

23. Zaščerinska, Jel̦ena, Ahrens, Andreas. (2010). Social Dimension of Web 2.0 in Teacher Education: Focus on Peer-Learning. Proceedings of London International Conference on Education (LICE2010), September 6-8, (pp. 182-187). London, UK.

24. Zaščerinska, Jel̦ena. (2011b). Social Dimension of Web 3.0 in Engineering Education, in Bassus, O.; Ahrens, A.; Lange, C. (Ed.) Information and Communication Technologies in Engineering and Business. Berlin: Mensch \& Buch. P. 101-130.

\begin{tabular}{|cl|}
\hline Andreas Ahrens & Faculty of Engineering, Department of Electrical Engineering and \\
& Computer Science, Hochschule Wismar, University of Technology, \\
& Business and Design \\
& Philipp-Müller-Straße 14, 23952 Wismar, Germany \\
& E-mail: andreas.ahrens@hs-wismar.de \\
& Phone: +49 3841 753330, Fax: +49 3841 753130 \\
\hline Jel̦ena Zaščerinska & Centre for Education and Innovation Research, \\
& Kurzemes prospekts 114, Rīga, LV-1069, Latvia \\
& E-mail: knezna@inbox.lv, Phone: +371 29435142 \\
\hline
\end{tabular}

